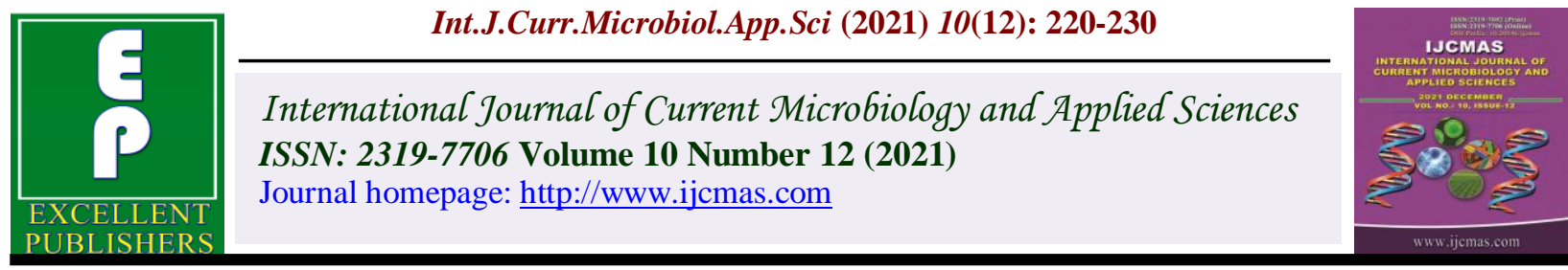

Review Article

https://doi.org/10.20546/ijcmas.2021.1012.026

\title{
Functional Foods: General Analysis and Development in the Food Industry
}

\author{
Jimmy Bladimir Alba*, Carmen Esmeralda Guambuguete, Andrea Lizbeth Hachi and \\ Jenny Esmeralda Quilo y Carlos Jácome
}

Universidad Estatal de Bolívar, Facultad de ciencias Agropecuarias, Recursos Naturales y del Ambiente, Carrera de Agroindustria, Laguacoto II, (km 1 11/2 Vía - San Simón), Guaranda, Ecuador

*Corresponding author

Keywords

Functional foods, Vegetables, Fruits, Nutrients, Health, Sugars, Benefits

\section{Article Info}

\section{Received:}

08 November 2021

Accepted:

05 December 2021

Available Online:

10 December 2021

\section{A B S T R A C T}

A study of certain foods was carried out on their bioactive compounds, which help in the treatment and prevention of some diseases, resulting in a global trend, conditioned by scientific and technological development, which has attracted the attention of academic sectors and organisms. International organizations to research on the subject. Method: Within this work a broad bibliographic review of functional foods with its general analysis and development within the food industry is demonstrated. Development: A functional food is one that has been elaborated by adding biologically active components that fulfill a specific function and improve health by establishing the origin and applying technological tools to obtain new products and supply market demand. The varied possibilities for the development of functional foods, based on the combination of a common food consisting of a variety of ingredients with biological activity, on the elimination of unwanted components or on the modification of others, making this range of products is currently marketed with a rapid increase.

\section{Introduction}

Functional foods are foods that do not depend on the contribution of nutrients, and that have been scientifically proven to have beneficial effects on one or more functions of the body, thus contributing to a better state of health and safety. These foods also have a protective function because they reduce the risk factors that result from the appearance of diseases. Among the most important functional foods are fortified foods (Flórez \& Torres, 2018).

The development of functional foods is a challenge that requires interdisciplinary research and collaboration between academics and industry scientists. An important issue is the identification and validation of relevant 
markers for use in a new generation of human nutrition studies based on hypotheses that demonstrate relevant health benefits and / or reduced risk of disease, it is clear that the food or food ingredient when that this concept is applied must be safe according to all food risk assessment criteria (Peréz, 2014).

In the future, food will not only allow optimal growth and development from pregnancy and at all stages of life, but will also enhance physical and mental capacities, in addition to reducing the risk of disease (Aguirre, 2019).

Global food trends in recent years show great consumer interest in certain foods that, in addition to their nutritional value, provide benefits for the physiological functions of the human body. These changes in eating habits have created a new area of development in food science and nutrition that corresponds to the field of functional foods. (Méndez, Torres, Acuña, \& Miguel, 2020).

A review of scientific articles was carried out during the months of May to November 2021, in English and Spanish in Ibero-American scientific journals indexed in Scielo, Biomed Central, Free Medical Journals, Redalyc, Inbiomed, Dialnet, innova Research Journal, Revista de Investigaciones Agropecuarias, Brazilian Journal of Food Technology, among others, using terms for the validation of keywords and the development of functional food information.

Articles published in the period from 2007 to 2019 were used to a greater extent. A total of 60 articles were obtained, they were applied inclusion and exclusion criteria consistent in force and contribution to the topic to be treated, where finally a total of 44 were selected related to the research topic, with which a database was built from which a bibliometric analysis was carried out for its systematization by topic of interest, authors, journals and publication dates.

\section{Developing}

\section{Origin of functional foods}

According to (Flórez \& Torres, 2018), in 1924 functional foods were discussed for the first time with the application of a preventive measure of goiter, consisting of the enrichment of salt with iodine in the State of Michigan. In the 1930s, Dr. Minoru Shirota started in Japan, this country was a pioneer in establishing an approval system for functional foods, since for the research and development of these foods, fermented milk is its great importance lies in the prevention of gastrointestinal diseases (Escobar, 2007).

By the 1950s, the World Health Organization (WHO) established food fortification programs to fight malnutrition in disadvantaged areas. However, since 1000 B.C. describe functional foods as processed, modified that play a specific role in the physiological functions of the body (Masís, 2001). A functional food provides the basic nutrients which acquires a new therapeutic and preventive approach; It is considered as a protective factor against a long series of pathological circumstances (Rodríguez, Megías, \& Baena, 2003).

\section{Current status of functional foods}

Functional foods have a great impact in the field of nutrition and consumption, which in turn have acquired a great advantage in the market, consuming functional foods provides basic nutrition, it is one of the innovative aspects of the products giving added value to the food products, which lays the importance for health, economy, scientific research, legislation, trade and market development since many studies have carried out the health effects of functional foods, their habitual consumption has been verified and closely related to disease prevention (Runiano \& Aguilar, 2006). Currently there are many 
functional foods in the world, with different nutraceutical components, with a favorable and specific function for the human organism (Abadía, 2003).

\section{Design of a functional food}

(Gonzales, 2018), a food can be designed for the elimination of components known to cause harmful effects to consumers, elimination of allergens, increasing the concentration of a component present in the food, current lifestyle trends do not They obtain adequate nutrition, which leads to overweight, obesity and malnutrition, consequently the development of functional foods, are highly outstanding for their content of nutrients and bioactive components, however disciplinary areas such as engineering, food science, chemistry, nutrition, pharmacy and statistics. Functional food tends to be described as food products that provide specific health effects, with nutritional components (Hidalgo, 2017).

\section{Habits and times}

Eating habits are the expression of their beliefs and traditions and are linked to the geographical environment and, as has been said, to food availability in which these factors evolve over the years and constitute the response to new lifestyles., to the new innovated products to be consumed, A food can be considered functional if it is shown that, in addition to having an adequate nutritional effect, it beneficially affects one or several functions of the organism in such a way that it contributes to improving health and optimal growth and development for the human being (Garca, Mateos, Diaz, \& Prato, 2018).

\section{Benefits of functional foods}

Functional foods are beneficial to health so it is important that foods are safe and have nutritional value, routinely consuming these foods provide vitamins, minerals and proteins that help strengthen the immune system, improve the functioning of the nervous system and allow the correct development of the organism, they also help in the prevention of diseases and improve health (Meneses, Molina, \& Vargas, 2011). The foods in this group can be natural foods with added, subtracted or modified value, the most frequently used functional components in this category include dietary fiber, antioxidants and antioxidants. Vitamins (C, D, A) and minerals such as calcium, iron and folic acid (Andrés, 2003). There is a high decrease in food among consumers, which is accentuated by the increase in the population, a phenomenon that is not the heritage of developed countries (Illanes, 2015).

\section{The food industry and the development of functional foods}

Functional foods in the food industry have been incessant for some years, especially in health, in 1984 in Ottawa, Braverman, the food industry has undergone an impressive development in the creation of this type of food during the last thirty years (Díaz, Illanes, \& Álvarez-Dardet, 2012). Therefore, a more nutritious type of food has begun to be produced, adding nutrients, fatty acids and prebiotics. (Aguirre, 2019). Consumer behavior around food selection, the industry has responded to these market demands, which is consistent with the findings on the effects of diet on human health (Braverman, 2001).

The development of functional foods arises in order to improve the current market situation that respond to the demands in health and quality, the provision of this type of products in supermarkets and the advertising that is developed, greatly affects consumer behavior and, therefore, poses new challenges for nutritional food education (Masís, 2001). 
According to (González, Ancona, Flores, \& Castillo, 2019), the integral use of fruits is a requirement of the characterization of foods and by-products to obtain natural extracts from by-products and the application of the components obtained to development of new functional foods The phenolic compounds in processed fibers of the juice industry, in particular fruits such as: apple, pear, peach, orange, tangerine, lemon and carrot as a vegetable, identified the concentration of around forty phenolic compounds, both those linked to epicarp (peel) and mesocarp (pulp) giving added value to each fruit in order to guarantee development and functional products (Lamos, Díaz, Sánchez, \& Girón, 2018).

\section{Healthy foods of low nutritional value}

Functional foods are consumed in normal portions in the daily diet and can be of completely natural origin or those to which ingredients have been added that induce beneficial effects or that the technological treatment applied increases the bioavailability of their constituents (Davila, Sangronis, \& Granito, 2003). The property of inulin more extensively is its behavior as a prebiotic, defined by its selective ability to stimulate the growth of a group of bacteria such as (bifidobacteria and lactobacilli) (Madrigal \& Sangronis, 2007).

The prototypes of the food are essentially onion and garlic, since the food is used as seasonings or spices, both products are healthy foods due to their high contribution of flavonoids, polyphenolic compounds with antioxidant properties and sulfur-containing organ compounds (Araya-L \& Lutz-R, 2003). According to (Delaquis \& Mazza, 1998), they affirm that the high inulin content of the onion is composed of what is not digested or absorbed at the level of the small intestine, ferments at the colon level and selectively stimulates the development of lactic bacilli that They are called probiotics and are beneficial for intestinal ecology, however, their nutritional contribution is low.

\section{Post-hoc dietary patterns}

Dietary patterns can be generated using criteria according to current scientific knowledge of human nutrition, or later by evaluating statistical methods, the usual methods used in nutritional epidemiology to generate a posteriori dietary patterns are: factor analysis that contains the approach of principal components and analysis by groups. The analysis of the dietary pattern is used as an alternative and complementary approach to the usual food and nutritional analysis (Babio, Bulló, \& Salas-Salvadó, 2008).

By means of statistical methods it is established that the factorial analysis in the underlying dietary patterns in the population under study has identified a so-called prudent dietary pattern, characterized by a higher consumption of fruits, crimsons, vegetables, whole grains, characterized by a high intake of processed meat, fried potatoes, dairy products and refined cereals (Bordonada, 2017).

\section{Healthy and functional food with good nutritional value}

Natural or processed foods that contain bioactive compounds are considered functional, which are defined amounts, and are not toxic, provide a health benefit which prevents chronic diseases (Galarza, 2019). Any food that comes close to the nutritional recommendations is usually recognized as healthy, and if it also contains a component that provides additional benefits, it can become functional as long as it is scientifically confirmed (Jáuregui- Lobera \& López, 2018). 


\section{How to determine the difference of a functional food from a conventional one}

To determine the difference between a functional food and a conventional one, science plays a determining role within functional food, an exhaustive review by experts in the field must be carried out, where the studies of the organic functions of the foods that are used are covered are going to process that enables their use by artificial or natural methods applied to the products, considering as a first measure their benefit to health and their nutritional properties, in addition to considering that access to ingredients and this guarantees an offer that supplies the demand of the food, which in turn opens up a broad field of research for nutrition and health specialists (López \& Mestre, 2015).

\section{Food market and consumer orientation}

One possibility to take advantage of the nutritional qualities of pejibaye is the preparation of tortilla-chip type sandwiches, currently with high demand in the international market, said product can be prepared with an advantage over those commercialized, since it can be manufactured without added fat, salt nor artificial additives (Calvo, Pérez, Guillén, Villaplana, \& Castro, 2015).

The positioning of this type of food products is highly favored due to multiple factors, among which the following stand out: the greater social recognition of the role that diet plays in the prevention and cure of diseases, the greater access to information by the consumer., the need to have processed foods that ease work in the face of the pressures that modern life demands, the possibility of substituting natural foods for supplements either by applying transgenic foods that contain ingredients from a genetically modified organism (Masís, 2001).

\section{Accessible food for society}

It is made up of male and female consumers, who make their purchases at the Fairs, thus called the shopping centers that bring together wholesalers, retailers and local producers of the most varied areas, within the same place, allowing direct access to the public and with prices accessible (Provens, 2013).

This has multiple conditioning factors, such as poverty, one of the main modifiable health risk factors. Thus, I dare to say that we do not need new healthy foods, but rather improve access to existing ones, that is, that they meet the requirements to integrate a balanced diet: fruits, vegetables, legumes and water (Intriago \& Barbosa, 2019).

These, although they are presented as the culmination of scientific food, exploit reducing versions of corporeality, erasing meaning and social dynamics and referring to mere biology, as if the diner were an intestine that must be controlled and modeled from inside (Aguirre, 2019).

\section{Prebiotics, probiotics and symbiotics and antioxidants}

Probiotics are called a wide group of nonpathogenic bacteria, which have various potential health benefits, and which have been used for centuries in the form of fermented milk-based products, such as yogurt (Arengas \& Marín, 2019).

The demand of the national and international market has promoted in recent years a new line of probiotic functional foods, food products that, in addition to their intrinsic nutritional value, help to maintain the general state of health of the body and at the same time can have a beneficial effect additional, therapeutic or preventive in the host (Taranto, Medici, \& Font, 2005). 
It is important to include foods rich in prebiotics and probiotics in the daily diet thanks to its usefulness in reducing the risk and treating various gastrointestinal diseases (Lamos, Díaz, Sánchez, \& Girón, 2018), since the combination of probiotics and prebiotics in food products as functional ingredients it becomes increasingly interesting for the food industry (Cadena, et al., 2014).

\section{Glucosinolates as functional ingredients}

Among the vegetables is broccoli, of the cruciferous family, of limited consumption in Spain, but an excellent source of phytochemical compounds, of which it is worth highlighting: glucosinolates, vitamins $\mathrm{C}, \mathrm{E}$ and $\mathrm{K}$, folates and phenolic compounds, in addition to essential minerals for consumer health (Fernández \& Viguera, 2008).

Isothiocyanates are powerful inducers of human and mammalian cytoprotective enzymes, they are metabolized through the mercapturic acid pathway, initially they are conjugated with glutathione, catalyzed by glutathione transferase (GST), the conjugate undergoes a series of reactions catalyzed by glutamyltranspeptidase cysteinylglycinase (CGase) and Nacetyltransferase (AT), forming conjugates of $\mathrm{N}$-acetylcysteine or mercapturic acids (Villanueva \& Cruz, 2019).

\section{Functional Lactic Foods}

According to (Álvarez, 2003) scientific evidence on the relationship between food and health has led to the emergence of a new fastgrowing food market in recent years: functional foods. At a global level, there is a great concern of people to maintain good health, or improve health through the consumption of traditional foods, or new foods, such as those designed for specific populations such as children, pregnant women or the elderly.

People frequently consume fortified milk, especially at breakfast, and they recognize yogurts as functional foods, however, they do not consume them or consume them occasionally (Mara, 2019). Consumers often search the market for products that contribute to their health and well-being without knowing that these are called functional foods (Gomez, 2012).

\section{Functional foods in meat}

The nutritional value of meat products is very well known, their healthiness can be improved, according to the scientific bases previously exposed, balancing their omega-6 / omega-3 ratio. Naturally, most meats have an omega- 6 / omega-3 ratio greater than 15 . The most favorable strategy to reduce this value is to incorporate the necessary amount of omega3 PUFA into meat products. To obtain a greater healthy effect, the incorporated omega3 PUFAs must be long-chain (such as EPA and DHA) and dosed specifically according to the lipid profile of the specific product (Reglero G, 2004).

\section{Meat derivatives as functional foods}

Nutrition science has traditionally studied the relationship between health and diet. Diets have been based on food combinations, designed to provide the human body with the nutrients that are required in different physiological situations.

The diets have been based on food combinations, designed to provide the human body with the nutrients that are required in different physiological situations (Meneses, Molina, \& Vargas, 2011). 
Table.1 Examples of studies on bioactive compounds in functional foods with potential benefits in human health.

\begin{tabular}{|c|c|c|c|}
\hline $\begin{array}{l}\text { Bioactive } \\
\text { compounds }\end{array}$ & $\begin{array}{c}\text { Potential examples of } \\
\text { application in agribusiness }\end{array}$ & Potential benefits & References \\
\hline $\begin{array}{l}\text { Probiotics, } \\
\text { prebiotics and } \\
\text { symbiotics } \\
\text { symbiotics }\end{array}$ & $\begin{array}{l}\text { Encapsulation by lyophilization } \\
\text { of probiotic strains in mixtures } \\
\text { with prebiotic agents during } \\
\text { food storage, livestock diets with } \\
\text { symbiotic products. }\end{array}$ & $\begin{array}{l}\text { Regulates intestinal } \\
\text { transit and balances } \\
\text { intestinal flora, reduces } \\
\text { problems associated } \\
\text { with colon cancer. } \\
\text { reduces problems } \\
\text { associated with colon } \\
\text { cancer. }\end{array}$ & $\begin{array}{l}\text { Rodríguez et al. } \\
\text { (2015); Salazar et } \\
\text { al. (2015); Olveira } \\
\text { and González } \\
\text { (2016). }\end{array}$ \\
\hline Dietary fiber & $\begin{array}{l}\text { Addition of vegetable fibers in } \\
\text { bakery products, production of } \\
\text { cookies, ice cream, meat foods } \\
\text { and concentrates from fiber } \\
\text { obtained from the epicarp of } \\
\text { vegetables. }\end{array}$ & $\begin{array}{l}\text { Reduction of } \\
\text { constipation and proper } \\
\text { functioning of the colon, } \\
\text { reduction of cholesterol } \\
\text { and glucose levels in the } \\
\text { blood. }\end{array}$ & $\begin{array}{l}\text { Alarcón et al. } \\
\text { (2015); Crizel } \\
\text { (2015); Guedes et } \\
\text { al. (2016); Torres et } \\
\text { al. (2016); Okiyama } \\
\text { et al. (2017); } \\
\text { Benitez et al. } \\
\text { (2018); Djurle } \text { et al. } \\
\text { (2018). }\end{array}$ \\
\hline Fatty acids & $\begin{array}{l}\text { Enrichment with omega } 3 \text { and } 6 \\
\text { in eggs, bread making, meat } \\
\text { products such as chicken (with } \\
\text { the help of the supplement of } \\
\text { compounds such as flaxseed in } \\
\text { the animal feed), oil in seeds, } \\
\text { legume leaves and fish. }\end{array}$ & $\begin{array}{l}\text { They exert } \\
\text { cardiovascular } \\
\text { protection such as } \\
\text { hypertension or } \\
\text { ischemia as an anti- } \\
\text { inflammatory agent. }\end{array}$ & $\begin{array}{l}\text { Colussi et al. } \\
\text { (2016); Rasti B. et } \\
\text { al. (2017); } \\
\text { Konieczka, } \\
\text { Czauderna y } \\
\text { Smulikowska, } \\
\text { (2017). }\end{array}$ \\
\hline $\begin{array}{l}\text { Phenolic } \\
\text { compounds }\end{array}$ & $\begin{array}{l}\text { Enrichment of phenolic } \\
\text { compounds in fruit juices such } \\
\text { as: apple, pear, peach, orange, } \\
\text { mandarin, lemon and carrot as a } \\
\text { vegetable, high content in olive } \\
\text { oil, extracts of garlic peel, } \\
\text { onions, as in rosemary, moringa } \\
\text { and en freeze-dried beer. }\end{array}$ & $\begin{array}{l}\text { They present an } \\
\text { antioxidant effect and } \\
\text { exert favorable effects } \\
\text { on the lipid profile as } \\
\text { well as antimicrobial } \\
\text { action. }\end{array}$ & $\begin{array}{l}\text { Rius et al. (2015); } \\
\text { Vieira } \text { et al. (2016); } \\
\text { Deng et al. (2017); } \\
\text { Chhouka et al. } \\
\text { (2017); Beretta } \text { et } \\
\text { al., (2017). }\end{array}$ \\
\hline Phytoestrogens & $\begin{array}{l}\text { Enrichment of phytoestrogens in } \\
\text { chicken eggs, foods derived } \\
\text { from soy, wheat, rye. }\end{array}$ & $\begin{array}{l}\text { It prevents osteoporosis, } \\
\text { antioxidants, anticancer } \\
\text { agents, reduces the risk } \\
\text { of chronic diseases. }\end{array}$ & $\begin{array}{l}\text { Mattioli et al. } \\
\text { (2016); Idehen } \text { et al. } \\
\text { (2017); Raheja, } \\
\text { Girdhar, Lather y } \\
\text { Pandita (2018). }\end{array}$ \\
\hline \multirow[t]{2}{*}{ Flavonoids } & $\begin{array}{l}\text { Coating with propolis on meats } \\
\text { to evaluate the antioxidant } \\
\text { action. }\end{array}$ & $\begin{array}{l}\text { Application of edible } \\
\text { flower and leaf extracts. } \\
\text { They are effective in } \\
\text { controlling the oxidative } \\
\text { process of lipids, } \\
\text { extending the useful life } \\
\text { of products. }\end{array}$ & $\begin{array}{l}\text { Biluca et al. (2016); } \\
\text { Machado et al. } \\
\text { (2016); Kunrath et } \\
\text { al. }(2017) .\end{array}$ \\
\hline & Enrichment of flour in tortillas, & They are an important & Rutz et al. (2016); \\
\hline
\end{tabular}




\begin{tabular}{|c|c|c|c|}
\hline \multirow{7}{*}{ Carotenoids } & $\begin{array}{c}\text { microencapsulation of lycopene } \\
\text { in cakes, curmuma in ice cream } \\
\text { and yogurt, carotenoids in fatty } \\
\text { acids, provitamin A, enrichment } \\
\text { of snacks, use of agro-industrial } \\
\text { by-products such as colorants } \\
\text { and antioxidants. }\end{array}$ & $\begin{array}{c}\text { source of carotenoids } \\
\text { that have antioxidant } \\
\text { properties, and they also } \\
\text { provide benefits in } \\
\text { cognitive, ocular and } \\
\text { cardiovascular function. }\end{array}$ & $\begin{array}{c}\text { Martínez-Girón, } \\
\text { Figueroa-Molano } \\
\text { and Ordóñez-Santos } \\
\text { (2017); } \\
\text { Eggersdorfer and } \\
\text { Wiss (2018). }\end{array}$ \\
\hline
\end{tabular}

Source:(Lamos, Díaz, Sánchez, \& Girón, 2018).

Fig.1 Knowledge and inclusion in the diet of milk and dairy products added with functional ingredients (Lamos, Díaz, Sánchez, \& Girón, 2018).

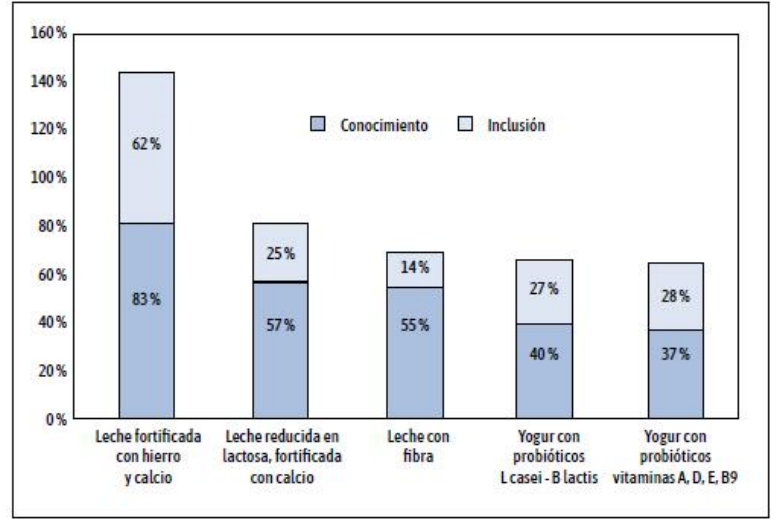

\section{Food consumption trend}

We are living what is currently called an "epidemiological transition", since our causes of disease and mortality begin to be different from those that afflicted us thirty or fifty years ago (Valenzuela, Valenzuela, Sanhueza, \& Morales, 2014). They present a constant dynamism, and can be reflected as a temporary preference or become a permanent force in the market since they are conditioned by several factors, such as income level, environmental changes, altered diets, population increase and demographic variations (Añazco, Vásquez, \& Illescas, 2021).

\section{Competitiveness in the functional food} industry

The ability to innovate to access a local market that is structured in niches and is in training, for the generation of knowledge and access to technology is essential, therefore public science and technology institutions, such as INTA and Universities, are important to accompany this type of process, particularly SMEs, which add value to primary productions (Cámpora, 2016). The development of functional foods with antioxidant activity based on the diversification of their commercialization, not only as dry calyces but also as a common ingredient or excipient of high value for the food industry (Martínez, et al., 2014).

Functional foods are the reason for science and biology in order to produce beneficial effects on organic and nutritional functions. Among these foods, its main ingredient are probiotics, prebiotics, Omega 3 fatty acids, antioxidants, phytosterols and especially flavonoids, in order to help and satisfy new lifestyles for a balanced diet.

Functional foods for agribusiness are the 
greatest challenge towards conducting new studies in obtaining products with food matrices that can conserve and preserve bioactive compounds, thus improving healthy eating and becoming a source of action for the food industry.

\section{References}

Abadía, P. F. (2003). Sobre Los Alimentos Funcionales. Rev Esp Salud Pública, 7 - 8. Obtenido de https://www.scielosp.org/article/ssm/conten t/raw/?resource_ssm_path=/media/assets/re $\mathrm{sp} / \mathrm{v} 77 \mathrm{n} 3 / \mathrm{editorial} 2$

Aguirre, P. (2019). Alimentos funcionales entra las nuevas y viejas corporalidades. Dialnet, 95-120. Obtenido de https://dialnet.unirioja.es/descarga/articulo/ 6832409.pdf

Álvarez, J. R. (2003). Nutrición y Salud. Nuevos alimentos para nuevas necesidades. España: Nueva Imprenta.

Andrés, R. U. (2003). Guia de los alimentos funcionales. Sociedad Española de Nutrición Comunitaria (SENC), 7-8. Obtenido de https://www.fesnad.org/resources/files/Publ icaciones/guia_alimentos_funcionales.pdf

Añazco, R. E., Vásquez, D. P., \& Illescas, M. G. (2021). Los superalimentos como tendencia del mercado: Un análisis de las oportunidades para las empresas exportadoras. Innova Research Journal, 157-179.

Araya-L, H., \& Lutz-R, M. (2003). Alimentos Funcionales y saludables. Revista Chilena de nutricion, 8-14. Obtenido de https://www.scielo.cl/scielo.php?script=sci_ arttext\&pid=S0717-75182003000100001

Arengas, M. A., \& Marín, B. E. (2019). Los probióticos: alimentos funcionales para lactantes. Medicas UIS, 31-39.

Babio, N., Bulló, M., \& Salas-Salvadó, J. (2008). Patrones dieteticos asociados al sindrome metabolico. Actualizacion en Nutricion, 300-310. Obtenido de https://www.researchgate.net/publication/20
9499244_Patrones_dieteticos_asociados_al _sindrome_metabolico

Bordonada, M. Á. (2017). Nutrición en salud pública. Madrid: Escuela Nacional de Sanidad, Instituto de Salud Carlos III. Obtenido de http://gesdoc.isciii.es/gesdoccontroller?acti on $=$ download $\& \mathrm{id}=11 / 01 / 2018-5 \mathrm{fc} 6605 \mathrm{fd} 4$

Braverman, V. (2001). Alimentos saludables: treinta años de su existencia en el mercado. Soy Noticias, 1-19. Obtenido de https://www.scielo.sa.cr/scielo.php?script=s ci_arttext\&pid=S1409-

14292002000100004

Cadena, R., Caimi, D., Jaunarena, I., Lorenzo, I., Vidal, L., Ares, G.,... Gimenez, A. (2014). Comparison of rapid sensory characterization methodologies for the development of functional yogurts. Food Research International, 446-455.

Calvo, R. L., Pérez, A. M., Guillén, C. I., Villaplana, S. C., \& Castro, M. L. (2015). Evaluación de la aceptación por consumidores de un bocadillo de pejibaye (Bactris gasipaes) y estudio de su potencial como alimento funcional. Archivos Latinoamericanos de Nutrición, 51-58.

Cámpora, M. C. (2016). Alimentos funcionales: tecnología que hace la diferencia. Revista de Investigaciones Agropecuarias, 131-137.

Davila, M. A., Sangronis, E., \& Granito, M. (2003). Leguminosas germinadas o fermentadas: alimentos o ingredientes de alimentos funcionales. Archivos Latinoamericanos de Nutrición, 348-354. Obtenido de http://ve.scielo.org/scielo.php?script=sci_ar ttext\&pid=S0004-06222003000400003

Delaquis, P., \& Mazza, G. (1998). Functional vegetable products. En: G. Mazza, ed. Functional Foods. Biochemical and processing aspects. Technomic Pub. Co Lancaster, 193-233.

Díaz, C. G., Illanes, L. M., \& Álvarez-Dardet, C. (2012). Alimentos como medicamentos: la delgada línea divisoria entre la industria farmacéutica y la industria alimentaria. Revista Española de Salud Pública, 313317.

Obtenido de 
https://www.scielosp.org/article/ssm/conten t/raw/?resource_ssm_path=/media/assets/re sp/v86n4/01_editorial.pdf

Escobar, H. (2007). Alimentos funcionales ¿solución de todos los problemas? Gastrohnup, 4 - 5. Obtenido de http://revgastrohnup.univalle.edu.co/a07v9n 1/a07v9n1art3.pdf

Fernández, D. A., \& Viguera, C. G. (2008). El brócoli fuente de ingredientes funcionales: glucosinolatos. Alimentacion, Nutricion, Salud, 49-53.

Flórez, A. M., \& Torres, J. S. (2018). Beneficios Para La Salud, De Alimentos Funcionales, Producto De La Combinación De Frutos Nativos. Boletín Semillas Ambientales, 12(2), 67-77.

Galarza, V. O. (2019). Carbohidratos y proteínas en microalgas: potenciales alimentos funcionales. Brazilian Journal of Food Technology, 22. Obtenido de https://www.scielo.br/j/bjft/a/vDxNKVVFf RgTTBvz3JB9zzJ/?lang=es\&format=html

Garca, C. M., Mateos, J. M., Diaz, L. E., \& Prato, A. D. (2018). Alimentos Funcionales: aproximacion a una nueva alimentacion. En Alimentos Funcionales (pág. 238). Madrid: inutcam. Obtenido de http://www.madrid.org/bvirtual/BVCM009 703.pdf

Gomez, Z. A. (2012). Alimentos funcionales derivados de lactosuero y bacterias lácticas. En Aspectos probióticos y tecnológicos de las bacterias lácticas (págs. 107-126). Madrid: Editorial Academia Española.

Gonzales, D. O. (2018). Alimentos que mejoran la salud: panorama actual de los alimentos funcionales. Dialnet, 1 - 7.

González, M. I., Ancona, D. B., Flores, J. S., \& Castillo, C. G. (2019). Mermelada enriquecida con fibra dietética de cáscara de Mango (Mangifera indica L.). Tecnología en Marcha, 193-201. Obtenido de https://www.scielo.sa.cr/scielo.php?pid=S0 379-

39822019000100193\&script=sci_arttext

Hidalgo, M. (2017). Diseño de un alimento funcional como alternativa en reducción de malnutrición. Simulación y Laboratorio, 1-
2. Obtenido de https://www.ecorfan.org/bolivia/researchjou rnals/Simulacion_y_Laboratorio/vol4num1 3/Revista_de_Simulacion_y_Laboratorio_V 4_N13_5.pdf

Illanes, A. (2015). Alimentos funcionales y biotecnología. Revista Colombiana de Biotecnología, 5-8. Obtenido de http://www.scielo.org.co/scielo.php?script= sci_arttext\&pid=S0123-

34752015000100001

Intriago, I. E., \& Barbosa, Y. (2019). Los riesgos de manipulación de los alimentos funcionales y su importancia para la salud. Correo Científico Médico, 23(3).

Jáuregui-Lobera, I., \& López, M. J. (2018). Información no es conocimiento: propósito de los alimentos funcionales. Journal, 593$613 . \quad$ Obtenido de https://dialnet.unirioja.es/descarga/articulo/ 6521706.pdf

Lamos, D. A., Díaz, L. N., Sánchez, M. A., \& Girón, J. M. (2018). Alimentos funcionales: avances de aplicación en agroindustria. Tecnura 22(57), 55-68. Obtenido de https://www.redalyc.org/journal/2570/2570 57438004/html/

López, E. M., \& Mestre, J. B. (2015). Alimentos funcionales: ¿necesidad o lujo? Revista Española de Nutrición Humana y Dietética, 1-3.

Madrigal, L., \& Sangronis, E. (2007). La inulina $\mathrm{y}$ derivados como ingredientes claves en alimentos funcionales. Archivos Latinoamericanos de Nutrición, 387-396. Obtenido de http://ve.scielo.org/scielo.php?pid=S000406222007000400012\&script=sci_arttext\&tl ng=en

Mara, M. G. (2019). Conocimiento y consumo de alimentos funcionales en la comunidad académica de la Universidad Nacional del Chaco Austral. Ciencia, Docencia y Tecnología, 285-296.

Martínez, M. T., Carrillo, R. E., Sánchez, M. L., Ruiz, E. J., Morales, R. B., \& Herrera, L. M. (2014). Potencia de la Jamaica en la elaboracion de alimentos funcionales con actividad antioxidante. Revista Mexicana de 
Agronegocios, 1082-1088.

Masís, P. S. (2001). Alimentos funcionales: análisis general acerca de las características químicas - nutricionales, desarrollo industrial y legislación alimentaria. Revista Costarricense de Salud Pública, 14091429.

Méndez, M., Torres, A., Acuña, J., \& Miguel, J. (2020). Alimentos funcionales, bases conceptuales y su aplicación en el diseño de planes de alimentación. Biociencias, 15(1). Obtenido de https://www.medigraphic.com/pdfs/revsalp ubnut/spn-2002/spn023g.pdf

Meneses, S. M., Molina, D. R., \& Vargas, J. H. (2011). Derivados cárnicos como alimentos funcionales. Dialnet, 163-172. Obtenido de https://dialnet.unirioja.es/servlet/articulo?co digo $=4315777$

Peréz, S. (19 de Noviembre de 2014). Alimentos funcionales ajustados a la necesidad alimenticia ecuatoriana. Dialnet, 74 - 81. Obtenido de Dialnet: https://dialnet.unirioja.es/descarga/articulo/ 6087630.pdf

Provens, N. (2013). Grado de conocimiento acerca de los alimentos funcionales. En N. Provens, Universidad Fasta. Buenos Aires: UFASTA.
Reglero G, F. P. (2004). Mezcla oleosa de ingredientes bioactivos naturales para la preparacion de un producto alimenticio enriquecido. Patente.

Rodríguez, M. B., Megías, S. M., \& Baena, B. M. (2003). ALIMENTOS Funcionales Y Nutrición Óptima. Rev Esp Salud Pública 2, 1 - $15 . \quad$ Obtenido de https://www.scielosp.org/article/ssm/conten t/raw/?resource_ssm_path=/media/assets/re $\mathrm{sp} / \mathrm{v} 77 \mathrm{n} 3 /$ colabora

Runiano, S., \& Aguilar, G. G. (2006). Alimentos funcionales, una nueva alternativa de alimentación. Orinoquia, 1 - 9. Obtenido de.

Taranto, M. P., Medici, M. G., \& Font, G. M. (2005). Alimentos funcionales probióticos. Quimica Viva, 26-34.

Valenzuela, A., Valenzuela, R., Sanhueza, J., \& Morales, G. (2014). Alimentos funcionales, nutraceúticos y foshu: ¿vamos hacia un nuevo concepto de alimentación? Revista chilena de nutrición, 198-204.

Villanueva, E. Y., \& Cruz, V. R. (2019). La Maca (lepidium meyenii walpers) alimento funcional andino: bioactivos, bioquímica y actividad biológica. Revista de Investigaciones Altoandinas, 139-152.

\section{How to cite this article:}

Jimmy Bladimir Alba, Carmen Esmeralda Guambuguete, Andrea Lizbeth Hachi and Jenny Esmeralda Quilo y Carlos Jácome. 2021. Functional Foods: General Analysis and Development in the Food Industry. Int.J.Curr.Microbiol.App.Sci. 10(12): 220-230.

doi: https://doi.org/10.20546/ijcmas.2021.1012.026 